(C) The Author(s), 2021. Published by Cambridge University Press on behalf of The Hegel Society of Great Britain. This is an Open Access article, distributed under the terms of the Creative Commons Attribution licence (http://creativecommons.org/licenses/by/4.0/), which permits unrestricted re-use, distribution, and reproduction in any medium, provided the original work is properly cited.

\title{
Peer Gynt and Oedipus: Ibsen on Hegel's Precursors of Modernity
}

\section{Lior Levy}

\begin{abstract}
G. W. F. Hegel sees Oedipus as an epitome of the philosophical quest for self-knowledge. In Hegel's readings of Oedipus, the latter becomes a distant reflection of the modern and mature Hegelian self, who consciously takes on this quest. Yet unlike Oedipus, whose search for the truth about his past is characterized by both metaphorical and literal blindness, the modern self knows itself, precisely because it understands its past and can thus appropriate and situate itself in relation to the present. For Hegel, self-understanding entails grasping the proper relationship between past and present, which in turn necessitates acknowledging his own relationship to Oedipus. This essay examines Henrik Ibsen's turn to the Hegelian engagement with the past (Oedipus being one crucial moment in the Hegelian story of the history of self-consciousness), by focusing on one of the most enigmatic scenes in his 1866 drama, Peer Gynt, where the Norwegian protagonist is cast as Oedipus. The scene examines the drama's own past - through an engagement with a dramatic ancestor-and focuses on the influence of the past on fashioning modern European identity. Moreover, it offers a critique of how the past is utilized in the creation and consolidation of that identity. With this, Ibsen offers an implicit critique of Hegel's understanding of Oedipus, and his encounter with the Sphinx in particular. Revisiting Oedipus through its modern reception, Ibsen questions the act by which the past is revealed as such and is put to work in the service of a particular present.
\end{abstract}

What makes us specially at home with the Greeks is that they made their world their home; the common spirit of homeliness unites us both (LHP: 150/174). ${ }^{1}$

\section{Introduction}

Hegel's admiration for the homeliness of the Greeks, shining so splendidly because it reflects a German spirit, is manifest in the abundant references to Greek culture, art and political life in his work. Among the Greeks, Oedipus plays a prominent role in 


\section{Lior Levy}

the Hegelian system, appearing by name in his Aesthetics, Lectures on the Philosophy of Religion, Lectures on the Philosophy of History, the Philosophy of Right and in a veiled form in the Phenomenology of Spirit. Homeliness was certainly an issue for Oedipus, a man who was never at home, in Corinth as in Thebes, and whose life ended in exile, but for Hegel he prefigured the German spirit of homeliness. This to such an extent that Jean Hyppolite even suggests that readers of the Phenomenology of Spirit - a text in which spirit is portrayed as returning to itself from estrangement —envision 'the totality of this difficult and sinuous work as the veritable Oedipus tragedy of the human spirit in its entirety' (Hyppolite 1957: 18).

Hegel's investment in Oedipus is part of a moment of idealist engagement with tragedy in general, and with Oedipus Rex in particular (Goldhill 2015: 231-32). This essay focuses on the critical juncture in the reception of Sophocles' tragedy and the myth of Oedipus in the early years of the nineteenth century, turning to a dramatic re-enactment of the ancient tragedy in Henrik Ibsen's Peer Gynt, and reading it as a response to Hegel's reception of Oedipus Rex. Ibsen wrote Peer Gynt in 1866 during his sojourn in Rome, where he developed a close friendship with the Norwegian art historian Lorentz Dietrichson, a Hegelian (Aarseth 2001: 536-37; Gjesdal 2007: 67). It may have been during their excursions together in and around Rome to look at ancient art that Dietrichson introduced Ibsen to Hegel's views on art or perhaps even directly to Hegel's Aesthetics (Aarseth 2001: 536-37), in which Oedipus is discussed. ${ }^{2} \mathrm{I}$ hone in on one of the most enigmatic scenes in Peer Gynt, which on my reading re-enacts Oedipus' encounter with the Sphinx by casting Peer in the role of a specifically Hegelian Oedipus. This restaging allows Ibsen to parody the Hegelian engagement with the past and question the act by which the past is revealed as such and is put to work in the service of a particular present. ${ }^{3}$

For Hegel, Oedipus' story epitomizes the philosophical quest for selfknowledge, and Oedipus thus becomes a distant reflection of the modern and mature Hegelian self, who consciously takes on this quest. Yet unlike Oedipus, whose search for the truth about his past is characterized by both metaphorical and literal blindness, the modern self knows itself, precisely because it understands its past and can thus appropriate and situate it in relation to the present. Hegelian self-understanding entails grasping the proper relationship between past and present, which in turn necessitates acknowledging his own relationship to Oedipus. Yet the Hegelian return to Oedipus, his instalment as the ancestor of the moderns, is not untroubled. On the one hand, it is an act that signals a homecoming of sorts, a retrieval of Greece as the origin of modern self-consciousness and precondition for its emergence. On the other hand, positioning Oedipus as a cradle or home to modern minds introduces an element of otherness or split into this very origin. For Oedipus is known, indeed studied by Hegel, for his failure to recognize his own home, a failure that led to parricide and incest. Ibsen approaches Hegel's construal of Greece as the cradle of modern German consciousness by exploring the relationship between Oedipus and the 


\section{Peer Gynt and Oedipus}

Sphinx, or Greece and Egypt. His critique of Hegel's appropriation of Oedipus aims to show that despite Hegel's awareness of modern consciousness having a relationship to Oedipus, and thus, to otherness, he represses, or as I will show, digests, this otherness in constructing his narrative of spiritual development.

The next section focuses on Act Four of Peer Gynt, where, on my reading, Peer is cast as Oedipus and the unstable relationship formed by Hegel's reading of modern Europe, Greece and Egypt, is interrogated. Juxtaposing Ibsen and Hegel, the section focuses on riddles as a theme bringing together the ancient tragedy and its modern readings. Following the presentation of Ibsen's critique of Hegel, I turn in the ensuing section to Hegel's notion of cultural development as homecoming, and examine a particular trope that governs his idea of the self making itself at home- that of digestion. By studying his 1809 address on classical studies, given while he was rector of the Nuremberg Gymnasium, together with his philosophy of nature, I give an account of digestible and indigestible others, which returns to the idea that Hegel effaces the inherent relationship to otherness on which the notion of homecoming rests.

The final section of the essay turns to the role of mythopoesis in Peer Gynt. I argue that the drama's relationship to its own (fictional) mythology challenges Hegel's turn to Oedipus and Greek myth as foundation and origin of modern consciousness. The drama's refusal to portray itself as resting on stable mythological grounds is echoed in its dispersed poetic form, which offers itself as a critical alternative to the ambitious Hegelian narrative of modern self-discovery as a coming into maturity. Unlike the Hegelian modern spirit, which professes to have integrated selfhood and alterity, synthesizing them into a mature self-consciousness, the Gyntian self is fragmented and episodic, motivated by irrational interests and desires that cannot be harnessed into an overarching poetic narrative representing progress and maturation. The tragic structure that Hegel borrows from Sophocles' Theban trilogy, where opposition or conflict between two poles culminate in synthesis or reconciliation, is replaced in Ibsen by the poetic form of the allegory, which, as Leonardo Lisi has aptly described, is 'devoid of an internal teleology', and is instead 'severed into a series of isolated incidents which [...] have hardly any necessary linear, syntagmatic, order at all' (Lisi 2008: 54). While Ibsen does not suggest that the past is undetermined by the present, free of the interests of the knowing subject who restores it, his own playful return to Oedipus points to the blind spots in Hegel, mainly the latter's refusal to acknowledge his own investments in making Greece an anchor for the modern mind.

\section{Peer Gynt and Oedipus: setting up the encounter}

Peer Gynt and Oedipus are a rather unlikely couple. One is modern; the other ancient. The story of one is written as a series of fragmented sequences; the other's 


\section{Lior Levy}

narrative is tightly woven. While the Scandinavian hero of Peer Gynt retells and relives his past indifferently, light-heartedly, the Greek protagonist of Oedipus Rex flees his past in horror, reaching his tragic end. Nevertheless, the ancient tragedy's way of confronting past and present, of linking them in the story of Oedipus' journey toward self-knowledge, became formative for modern readers, who constructed their own identity in part by means of a self-conscious return to the past. By revisiting the trope of Oedipus, indeed by casting Peer as Oedipus in one of the drama's most enigmatic scenes, Peer Gynt not only examines its own past-through an engagement with a dramatic ancestor-nor merely uses the past as an influence in fashioning modern European identity, but also offers a critique of how the past is utilized in the creation and consolidation of that identity. ${ }^{4}$

The meeting between Peer and the Sphinx in Act Four immediately calls to mind the ancient encounter between Oedipus and the mythical creature. Like Oedipus, who when facing the Sphinx was in recoil from his past, Peer arrives at the foot of the giant creature in Giza after deciding, two scenes earlier, to abandon his past and reinvent himself as a travelling scholar, 'a true man of science' committed to discovering the truth of past ages. Prima facie, this act of selfreinvention follows a series of shifts in Peer's identity - he has already assumed the roles of an heir to the troll king, a merchant and a pagan prophet. Previous identities, however, were simply stumbled upon (his affair with the Dovre king's daughter begins after he tells her that he is, like her, a descendent of royalty), or resulted from choices that do not appear in the drama itself (appearing as an already wealthy merchant at the beginning of Act Four, Peer describes the work of fate (fatum) and luck (lykken) (Ibsen 2005: 180; Ibsen 2009: 74-75) that bestowed stature on him). But the decision to be a scholar seems to rest on a genuine choice. Peer depicts it as an act of self-retrieval, a way of reconnecting with earlier, deeper and more authentic passions- his childhood love of legends and his desire for truth. The harmony between the content of the decision-to be a scholar who deciphers the truth of the age - and its form — a process of self-recognition and self-knowledge (understanding his own true nature), seems to indicate that with this decision Peer has indeed found his true vocation. Pursuing this new path, Peer is a self-proclaimed solver of riddles, both his own and humanity's.

But despite having acquired the proper attire and appropriate gestures, Peer is unable to penetrate the truth of the world he encounters, which remains mysterious and inexplicable. Both the colossus of Memnon and the Sphinx, remnants of an ancient culture that Peer meets under his newly assumed role of scholar, remain alien to him cognitively and emotionally-he cannot decipher Memnon's song; he calls the Sphinx a monster, unable to classify and understand it. Both Memnon and the Sphinx seem no more than relics of a distant past, inherently impenetrable and enigmatic. Act Four disrupts the predominantly European itinerary of Peer's journeys, setting up, under the African sun, encounters with figures 


\section{Peer Gynt and Oedipus}

of alterity. As Elisabeth Oxfeldt points out, although Peer's portrayal of his identity for his European companions at the beginning of the act is based on an idea of cosmopolitanism - he boasts that he is Norwegian by birth, but a world citizen in spirit, tracing the international origins of his various traits (Ibsen 2005: 183; Ibsen 2009: 78) — his sense of self remains stably Western, for the long list of places and heritages that influenced his formation excludes any contributions from, for example, Islamic nations or cultures (Oxfeldt 2005: 144). Hence, despite Peer's attempts to familiarize the unknown, as he attempts to alleviate his perplexity by drawing comparisons between Memnon and the Dovre king, and between the Sphinx and the Boyg, he remains unable to fully fathom them.

Peer's sense of puzzlement in his encounter with the Sphinx reverberates in the reader. Commentators who have studied the abundant 'enigmatic passages' (Aarseth 2001: 535) in Act Four argue that the sudden transition from Norway to Morocco and then Egypt introduces a topographical break so great that the act as a whole is rendered resistant to 'mapping and comprehension' (Rees 2008: 158), that it lacks 'dramatic coherence and thematic relevance' (Aarseth 2001: 535) and, even, because of this, that it is 'the least satisfactory in the play' Johnston 1980: 191).

It is perhaps no coincidence that Peer's enigmatic sojourn in Egypt includes a visit to the Sphinx, a creature famous for its riddles. Hegel, for example, whose sphinx, I argue, becomes Ibsen's in his rendition of Oedipus, thinks of it as an epitome of riddles and enigmas (LFA: 350, 361/452, 465). Nonetheless, whereas Hegel—not unlike Oedipus himself - aims to solve the riddle of the Sphinx, conferring meaning on it by organizing the story of its past appearances into a cohesive narrative culminating in Hegel's present, Ibsen retains the sense of enigma, remaining suspicious of Hegel's attempt to constitute unity and comprehension. The encounter between Peer and the Sphinx thus revisits and re-evaluates the grand narrative of progress and development, a narrative in which questions and riddles are replaced by definite answers, articulated by mature and utterly self-conscious modern European subjects.

\section{I.i. Oedipus and the Sphinx: Hegel's version}

Hegel's fascination with Oedipus was manifested in recurring references to a particular episode in his story - the encounter with the Sphinx. This encounter is crucial because of the specific moment-itself absent from Sophocles' tragedy—of Oedipus' answer to the Sphinx's riddle. In the Phenomenology of Spirit, Oedipus is introduced as the one 'who was able to solve the riddle of the Sphinx itself' (PS: 9737). Later, in The Philosophy of History, Hegel refers more elaborately to 'the Greek legend $[\ldots]$ which relates that the Sphinx — the great Egyptian symbolappeared in Thebes, uttering the words: 'What is that which in the morning 


\section{Lior Levy}

goes on four legs, at midday on two, and in the evening on three?' Oedipus, giving the solution, Man, precipitated the Sphinx from the rock' (PH: 220/317). The encounter between Oedipus and the Sphinx is related in similar terms in his lectures on aesthetics (LFA: 361/465).

Crucial for Hegel is Oedipus' exceptional ability to answer the riddle posed by the Sphinx. In answering the riddle, Oedipus followed the Apollonian decree - 'know thyself'. He identified and acknowledged his humanity as that which the riddle was pointing at. He recognized a unity in the disjointed multiplicity of parts which made up the riddle, identifying thought or reason as the underlying principle of the natural being of humanity, as its essence. Hence, the answer manifested Oedipus' knowledge that the 'Inner Being of Nature is Thought', (PH: 220/ 317). Thus, it reveals Oedipus' very essence to be wisdom, setting him apart from other human beings. This wisdom is the source of Oedipus' power-he is, the final lines of Sophocles' tragedy remind us, the one 'who knew the answer to the famous riddle and was a mighty man' (Sophocles 1994: 483). According to Hegel, the answer given by Oedipus manifests a higher stage in the development of spirit; higher, that is, than the Egyptian sphinx, who was able to pose the question, but unable to offer a solution. Oedipus' solution of the riddle is the emblem of humanity growing into self-consciousness, and a realization of its essence-its humanity_in and through thinking.

Yet, Hegel goes on to note, the 'time honoured antique solution given by Oedipus-who thus shows himself possessed of knowledge-is connected with a dire ignorance of the character of his own actions. The rise of spiritual illumination in the old royal house is disparaged by the connection with abominations, the result of ignorance' (PH: 220-21/317). Hegel makes a link between Oedipus' knowledge, his spiritual illumination, and his moral transgressions of patricide and incest. Oedipus deciphered, from the riddle's plurality-four, to two, to three-its unity, the human. But he is unable to complete the search for origin in his own life; he remains a riddle to himself.

Indeed, in the ancient tragedy we find Oedipus obsessed with riddles, which he attempts to solve. He relentlessly searches after answers-first, concerning his own origins, following an insult from a drunken Corinthian who made him question the identity of his parents (Sophocles 1994: 404-6); and subsequently for the true cause of the plague that threatens Thebes (Sophocles 1994: 330-32); finally, he searches for 'the track of an ancient guilt, hard to make out', for the trace, that is, of King Laius' murder (Sophocles 1994: 337). In Sophocles' tragedy, the term for this 'guilt' is aitias (Sophocles 1994: 336), which in a legal context designates an accusation or a charge, but which later, in philosophical discourse, came to denote first principles or causes, as we find it in Aristotle's Metaphysics. In looking into those ancient accusations then, Oedipus, like the philosophers, is searching for explanatory principles, for the ultimate reasons or causes that govern the order of things. 


\section{Peer Gynt and Oedipus}

However, in Hegel's reading, although Oedipus is a proto-philosophical figure, he is not fully philosophical, as he is unable to complete the journey into introspection-a journey that can only be completed by the mature, Hegelian subject. Oedipus the knower remains ignorant; he is bound to remain a stranger to himself, until his tragic end. Describing the ontogenetic and phylogenetic journeys to self-consciousness in the Phenomenology of Spirit, Hegel thinks of them in a manner that is akin to Oedipus' journey. For the individual and for humanity as a whole, self-knowledge is achieved only once the self is estranged from what is familiarly known, since 'the familiar in general, precisely because it is well-known, is not known.' (PS: ๆ31) Just as Oedipus has not properly known himself until he became estranged from the self he thought he was familiar with (by discovering that the slayed stranger is his father, his wife is his mother, his children are his siblings) so all humans in their quest for self-knowledge must, over time, de-familiarize the familiar in order to properly know themselves. If Oedipus is to be taken seriously as a symbol for the quest for self-knowledge, then the present must be de-familiarized. In Oedipus' story, this happens once the past returns to the present. For Hegel, then, it is not only that Oedipus embodies the return of the past in his personal story; he also functions symbolically as a figure of the return of the past, of all that is other than the present self, in the universal quest for selfknowledge. Yet again, according to Hegel, Oedipus himself has wrongly claimed the past as his own - he is a tragic hero precisely because he has assumed moral accountability for acts, patricide and incest, that he committed unknowingly. ${ }^{5}$ Hence Hegel is both like and unlike Oedipus, and what allegedly distinguishes him from the latter is his awareness of his proper relationship to this past.

\section{I.ii. Peer's Oedipus}

Peer's excursions in Africa lead him to the Egyptian desert where he encounters the Sphinx, a relic from an ancient past. The meeting occurs at a time when Peer, admitting the failure of his attempt to reinvent himself as a Muslim prophet, turns from the business of heathen prophecies to the more learned pursuits of scholarly life. Weighing his options, he decides that it would be best for him to assume the identity of a traveling scholar: 'Suppose - as a well-traveled scholar, I studied the whole glut of the ages!' (Ibsen 2005: 201; Ibsen 2009: 106). As a veritable Hegelian, Peer asserts that there is nothing philosophical about divination, while the study of the past constitutes a genuine scientific pursuit.

With this newly assumed identity Peer adopts a Hegelian commitment to embark on a journey into the past, which, he immediately determines, will be the object of his study. Just like Hegel's journey, in the Phenomenology and elsewhere, into past forms of human experience, Peer aims to follow the path of the human race (menneskeslagtens vej) (Ibsen 2005: 201), tracing it as far back as he can (rejse 


\section{Lior Levy}

kronologisk så langt jeg rakker) (Ibsen 2005: 201) in order to understand how from those early seeds (det smá) (Ibsen 2005: 201) the world developed. Abandoning his identity as a prophet, and solemnly swearing to be committed to nothing but the truth, Peer swears to abandon all that is comfortable and familiar. This is by the same token to abandon what is deceptive ('to sever the ties that are holding you on every side to home and friends' (Ibsen 2005: 201; Ibsen 2009: 106)).

Peer's Hegelian commitment to understand the truth of his age through the lens of the past calls to mind Hegel's portrayal of the task of self-knowledge as involving self-estrangement, itself a formulization of Oedipus' own journey into self-knowledge. In breaking bonds with home and friends, Peer makes a similar decision to de-familiarize the world, severing the ties that connect him to the world and make him feel at ease there; it is an ease conducive to error regarding the world's true nature. Peer's pursuit of truth in the past recalls that of Oedipus in yet another, more direct way. Like Oedipus, Peer wants to trace the present back to its origins in the past, and claim that the very commitment to this task has led him to solve the riddle (or mystery) of his destiny! ('Nu har jeg løst min bestemmelses gåde’ (Ibsen 2005: 201)). In other words, like Oedipus, Peer finds the key to his destiny-his future -in understanding the past. Or, better put, only once he commits to the idea that the present must be fathomed through its relation to the past, is his destiny revealed to him.

It is as a traveling scholar emulating a Hegelian philosopher that Peer enacts the scene of Oedipus' encounter with the Sphinx, a scene that is crucial, as we saw, to Hegel's philosophical notion of a journey into self-knowledge. Yet, famously, Oedipus' Sphinx stood just outside Thebes, not in the Egyptian desert. Are we correct in seeing Peer's encounter as Ibsen's adaptation of the Oedipus topos? To answer this question, I want to return again to Hegel's portrayal of the meeting between Oedipus and the Sphinx in The Philosophy of History, in a section that examines the cultural shift that occurs with the spatial and temporal transition from Egypt to Greece:

That the spirit of the Egyptians presented itself to their consciousness in the form of a problem is evident from the celebrated inscription in the sanctuary of the Goddess Neith as Sais: 'I am that which is, that which was, and that which will be: no one has lifted my veil.' [...] In the Egyptian Neith, Truth is still a problem. The Greek Apollo is its solution; his utterance is 'Man, know thyself.' In this dictum is not intended a self-recognition that regards the specialties of one's own weaknesses and defects: it is not the individual [...] but humanity in general is summoned to selfknowledge. This mandate was given to the Greeks, and in the Greek Spirit humanity exhibits itself in its clear and developed 


\section{Peer Gynt and Oedipus}

form. Wonderfully, then, must the Greek legend surprise us, which relates, that the Sphinx - the great Egyptian symbolappeared in Thebes, uttering the words: what is that which in the morning goes on four legs, at midday on two, and in the evening on three? Oedipus, giving the solution, Man, precipitated the Sphinx from the rock. The solution and the liberation of that Oriental Spirit, which in Egypt had advanced so far as to propose the problem, is certainly this: that the Inner Being of Nature is Thought, which has its existence only in the human consciousness. (PH: 220/316-17)

In this passage, Hegel associates the Greek sphinx with its Egyptian ancestor-and is amazed at the appearance of the latter in Thebes. For him, there is something particularly Egyptian about the Sphinx and hence it is almost unfitting for it to emerge in Greece. This is due to a crucial difference between the development of the Egyptian and the Greek spirit. Whereas the former lacks self-consciousness, the latter possesses it in its entirety. In his lectures on aesthetics, Hegel argues that the sphinx's shape, its human-animal hybridity, manifests its undeveloped spirit. In the sphinx, he says, human spirit 'tries to push itself forward, without coming to a perfect portrayal of its own freedom and animated shape, because it must still remain confused and associated with what is other than itself.' (LFA: 361/465) The sphinx finds the human enmeshed with the animal; it is thus unable to articulate its freedom and animation — which clearly belongs to the hands that made itindependently of lower forms of life. It is unable to express freedom in its own, human terms. Egyptian art, and the sphinx as its zenith, can be said to reveal spirit only symbolically. The relationship between the content-interiority, divinity, or spirit — and the medium in which content is expressed — in this case, the carved stone-remains wholly external in symbolic art. As a symbol, the sphinx is 'hinting' (LFA: 350/452) at its content by means of arbitrary conventions, but it remains 'confused and associated with what is other than itself' (LFA: 361/465). Symbolic art is thus perplexing and does not offer an internal logic with which it can be deciphered.

There is something particularly Egyptian about the sphinx, says Hegel, in that even in the Greek myth it 'appears as a monster asking a riddle.' (LFA: 361/465) If symbolic art is a riddle-asking about the human, but unable to articulate its humanity, in its own, properly human terms - then the sphinx is 'the symbol of the symbolic itself' (LFA: 360/465). The sphinx is the symbol of riddles; in its bizarre shape, no longer animal, not fully human, in its stiffness and rigidity, it puts itself forth as a question-What is this? Nonetheless, the sphinx is unable to provide an answer to this question. In this respect, the sphinx, like Neith, can only indicate the existence of the truth, to which it points by way of posing a 


\section{Lior Levy}

question. It cannot, however, retrieve the answer to its own question, and this answer remains buried in its dumb depths. Only with Oedipus' arrival, and his enactment of Apollo's decree 'know thyself', can the answer be articulated and the question solved. Oedipus recognizes what is essential to all humans, whoever they are. He reaches the answer by thinking, and in his answer identifies humanity with thought. Thus, only with Oedipus, and not with the Sphinx's asking of the question, could 'the light of consciousness' let 'its concrete content shine through' (LFA: 361/465).

The association between Oedipus' sphinx and Egypt must have dominated the European psyche. In 1867, the very year in which Peer Gynt was published, Jean-Léon Gérôme finished working on a series of canvases depicting Napoleon in Egypt (Ackerman 1986: 222). Among them was a famous painting depicting an encounter between General Bonaparte and the Sphinx (Fig. 1). The colossal sphinx dominates the scene. Across from it is a tiny Napoleon, alone on his horse, with the shadow of the French troops in the background. Yet, despite its size, the Sphinx is depicted as inferior to Napoleon-immobile and eaten by time, it is doomed to remain in the Egyptian desert, passively submitting himself to the light of the sun, which casts a shadow over half of its face. Napoleon, on the other hand, unimpressed by the sphinx, is visibly active. He has just arrived, as is revealed by the twitch of his horse's tail, and is about to depart. And when he leaves, it is for the Battle of the Pyramids (1789), where he will again demonstrate his superiority over the Egyptians, defeating the local Mamluk ruler and nearly eliminating the Egyptian army. To this painting, Gérôme gave the title Oedipe. ${ }^{6}$

Given the association between the sphinx and Egypt, it is no wonder that Peer as Oedipus meets his sphinx in the desert. In this Ibsen follows Hegel, and indeed the zeitgeist. Recall how in The Philosophy of History Hegel returns the Sphinx to Egypt, where he thinks it genuinely belongs: 'Wonderfully, then, must the Greek legend surprise us, which relates, that the Sphinx- the great Egyptian symbol-appeared in Thebes' (PH: 220/317). The Sphinx's appearance in Thebes is displaced, to ease the modern reader's surprise. We are reminded that the Greek Sphinx and its deadly riddle remained Egyptian all along.

The motif of riddles dominates the encounter between Peer and the Sphinx. The very appearance of the Sphinx provokes a series of questions, inducing in Peer an inquisitive mode, as he wonders: 'Now, where in the world have I seen before something I dimly remember, like this monster?' (Ibsen 2005: 203; Ibsen 2009: 109), and later again: 'But this fantastic mongrel creature, this changeling, half lion and half a woman,--Is he out of some legend [eventyr, translated also as 'fairytale'], as well?' (Ibsen 2009: 109; Ibsen 2005: 203). Peer describes the Sphinx as a 'skabilken' (Ibsen 2005: 203); an ugly, unidentified creature, of indefinite shape. This is in line with Hegel's comments on the hybridity of the sphinx, in which humanity, pushing forward, is nonetheless unable to manifest itself, and remains 


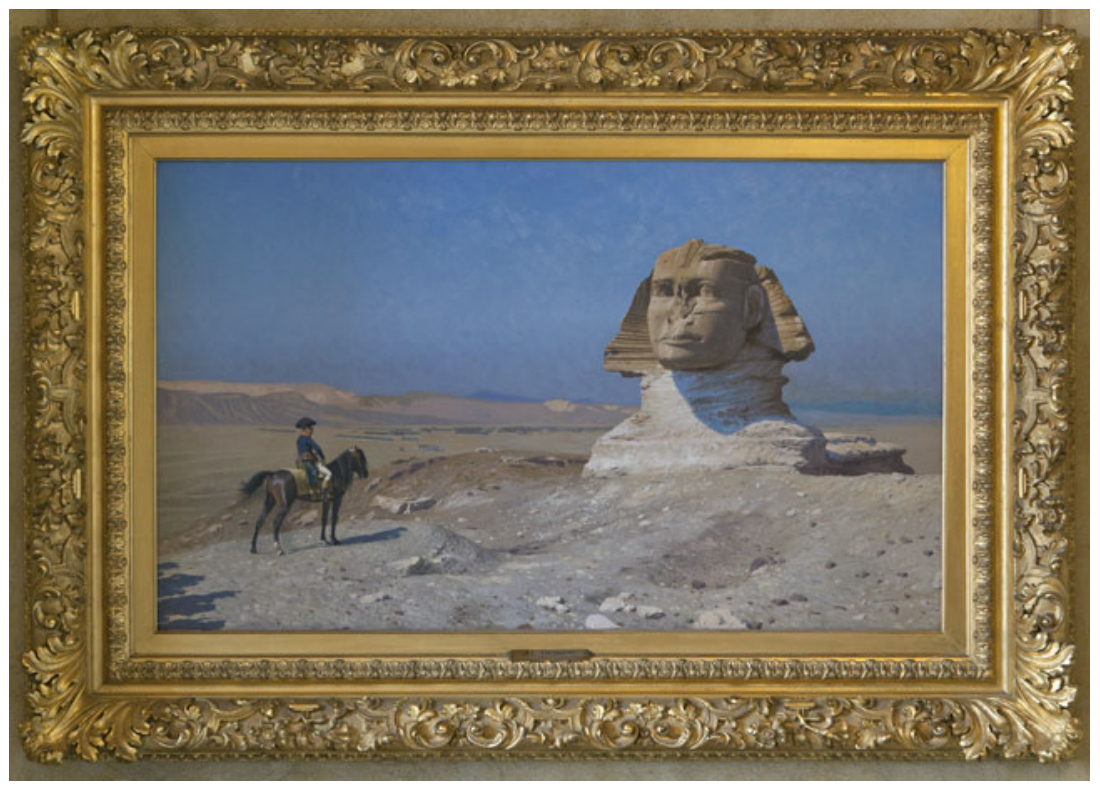

Figure 1. Gérôme, Jean-Léon. Bonaparte Before the Sphinx. 1886 CHearst Castle®/CA State Parks

enmeshed with and undifferentiated from its lower, animal form. In questioning himself, Peer decides that being able to decipher the mysterious appearance of the Sphinx is linked to locating its first appearance; the answer to 'what is that?' hinges on the answer to the more crucial question of where he has seen it before. And where has Peer, the learned scholar he now is, seen the Sphinx before? Surely, the origin of all things-sphinx is Sophocles' tragedy Oedipus Tyrannus, itself a version of a more ancient legend or fairy-tale, the Greek myth of Oedipus.

In his scholarly search for origins, Peer locates Greece as Egypt's 'before'. He reverses temporal order, turning the child into the father, just as Oedipus did. Or, perhaps, carrying the Hegelian developmental perspective to its logical conclusions, Peer is showing that the child-the undeveloped Egyptian consciousness - must come after the father- the mature Greek spirit. The inversion of temporal order, which places the Greek sphinx before the Egyptian one, suggests that the Egyptian riddle is legible as such—as a question that cannot disclose the answer contained in it-only from the perspective of an already fully formed Greek answer.

With this, Ibsen invites us to revisit the Hegelian understanding of the relationship between Greece and Egypt, civilizations which, in The Philosophy of History 


\section{Lior Levy}

are explicitly treated as temporally related, in the section 'Transition to the Greek World', which ends the analysis of 'The Oriental World'. In this text, Hegel identifies Africa as 'the land of childhood' and describes it as being 'shut up' and 'compressed within itself' (PH: 91/153). Egypt is locked away, shut within itself, forced into a position of an eternal child, situated 'beyond the day of self-conscious history [...] enveloped in the dark mantle of Night' (PH: 91/153). Egypt is 'the childhood of history' and as such it is only spatial, excluded from change, a-temporal. In Hegel's narrative, Egypt is 'unhistorical history' (PH: 105/171) a child deprived even of the right to grow up. Compared to the frozen, severe spatiality of the childish Egyptian consciousness, manifested in 'the colossal forms of oriental imagination, the Egyptian buildings of Eastern kingdoms', the plasticity of the 'beautiful' Greek 'gods, statues, and temples', says Hegel, 'may seem [...] to be like child's play' (LHP: 154/178). Nonetheless, the cultural treasures of the Greeks merely seem like child's play; in effect they are much more complex and manifold than the simple oriental forms. But no less crucial is how different the Greek seeming-child is from the actual Egyptian children. The Greeks are playful; if they are children at all, they are already in movement, about to embark on a journey towards adulthood (indeed, in The Philosophy of History the Greeks are compared to adolescents (PH: 106/172), identified with a moment that itself contains difference or movement, a transition from childhood to adulthood); their Egyptian ancestors, however, are children of a different kind-stubborn and motionless, they are doomed to remain infantile for eternity. ${ }^{7}$

Peer's search for the Sphinx's origins revisits Hegel's reading of Oedipus' encounter with the Sphinx. In his attempt to decipher the creature's appearance, Peer seeks to recognize it, both in the sense of understanding what kind of creature it is, and in the sense of becoming cognizant of its origins (where has he seen it before, for the first time?). With this, he comes into contact with Oedipus' quest for origins, or puts the question of origins itself into question. In the tragedy, Oedipus' identity materializes and he realizes who he is only once the past is called on to illuminate the present. In this respect, Oedipus' present depends on his past; without knowing who he was, he cannot fully be who he is. Hegel complicates the temporal order. Although he summons the past in order to de-familiarize the present, his reading of the Oedipus-Sphinx encounter shows that the present (the more developed temporal moment, either Hegel's own time in relation to Oedipus, or Oedipus' relation to Greece's Egyptian past) is necessary for making the past (for Hegel, Greece and Egypt; for Oedipus, only Egypt) intelligible. Peer's restaging of the Oedipus-Sphinx encounter, his rereading of Hegel's reading of Oedipus, points to the fact that by making Greece the source of the answer to the Egyptian riddle, Hegel himself chooses a past which renders his own present legible. It is a past which grounds and safeguards his modern identity-understood as a condition for ultimate legibility—as the foundation of knowledge. ${ }^{8}$ By making 


\section{Peer Gynt and Oedipus}

Greece superior to Egypt, Hegel consecrates Greece as his own tradition, the birthplace of the philosophical spirit that reaches fruition in Hegel's own time. Peer's own search for origins in the moment of his encounter with the Sphinx highlights that the past does not simply lie there, an inert datum, immanent to its own apparent horizons, but is rendered active and meaningful by the purposes of our own present.

In the Lectures on Fine Art, Hegel warns his readers against projecting their fully developed, European understanding of symbols onto the riddle of the Sphinx: 'In deciphering such a meaning we often, to be sure, go too far today because in fact almost all the shapes present themselves as symbols' (LFA: 360/ 464). According to him, the adequate mode of representation for fully rational, self-conscious moderns is philosophical thought, rather than art. In modernity, when humans express themselves in art, there is an intrinsic lack of correspondence between form and content. The relationship between the two is utterly accidental, or external; in other words, symbolic. With modern symbolism, the form is infused with meaning, and theoretical interpretations are responsible for spelling this meaning out (an idea which relates to Hegel's claim that ours is an era in which theories of art prevail over art). It would be a mistake, however, to treat the Egyptian symbol as modern and read meaning into it, since 'the Egyptian symbols [...] contain implicitly much, explicitly nothing' (LFA: 360/465). Hegel's advice not to go too far with our interpretations of the Egyptian symbol warns us against anachronistically imposing on Egypt something - meaning - that was originally absent from it; it suggests that it would be wrong to give a voice- a fully developed sense- - to something that was itself mute.

In Peer Gynt's list of dramatis personae, the sphinx is listed as 'stum person', that is, dumb. Whereas this description seems to affirm Hegel's portrayal of the Egyptian sphinx as devoid of genuine knowledge, Peer's encounter with the Egyptian relic challenges this view. Hegel insists that the sphinx cannot speak. In acknowledging that the mute, unidentifiable (skabilken) has its own origins, that it has a 'before', Peer lets us see that Hegel's view deprives this Egyptian symbol of a voice in order to safeguard the position of its progeny, its 'after'-Apolloas the origin of speech and answers. In other words, in placing Greece as Egypt's 'before', our interpretation silences any meaning or speech that the sphinx could have had. Or, alternatively we could say, that he points to the fact that the idea that the Egyptian sphinx contains 'explicitly nothing' (LFA: 360/465) already itself forces a foreign meaning onto it, imposing on it a silence that may not be its own. Indeed, in Peer Gynt, when the 'dumb' sphinx finally speaks, it does so in a 'Dialekt fra Berlin' or a 'Berlin dialect' (Ibsen 2005: 204; Ibsen 2009: 110), rehashing the point that the voice of the past does not come from nowhere, but is always produced in specific circumstances; it is a voice which above all echoes the particular present in which it comes into being. With this, Peer also questions Hegel's quest to 


\section{Lior Levy}

de-familiarize the present. For surely, in having Egypt stand on the shoulders of Greece and be the echo-chamber of the 'Berlin dialect', one has really not left home.

\section{Eating one's way home: Hegel on homecoming}

Journeys away from as well as back home are a theme, of course, not only of Oedipus Rex but also of Hegel's philosophy. The Phenomenology of Spirit is often read as an account of the journey that spirit undertakes, as it moves through human experience (Erfahrung, which itself contains an intimate connection to a journey, Fahrt), in what Hegel describes as 'a complicated, tortuous journey and $[\ldots]$ an equally immense and strenuous effort' (PS: $\mathbf{q 1 2}$ ). ${ }^{10}$ This laborious journey results in a 'reward' (PS: \12), and hence it should not be thought of, at least in retrospect, as aimless wandering, but as a voyage to a desired destination. (Hegel makes a related claim in The Philosophy of History, where he says that history progresses, that it is characterized by advancement, that its 'mutations' (PH: 54/105), its multiform of events, are becoming better and more perfect). ${ }^{11}$

The reward of the journey is spirit's self-recognition. Or, as Hegel puts it, 'the goal' is 'spirit that knows itself as spirit' (PS: $\mid 808)$. Beginning its journey in a mode of estrangement, taking what is properly its own as alien, spirit's move through history is 'a knowing, self-mediating becoming' (PS: ๆ808), a process by which it comes to recognize all that is exhibited to it, and which as such appears as other, as its own. History is spirit's movement through different epochs, different cultures. In the Phenomenology, these latter are at first presented as 'a gallery of images', as objects for spirit to contemplate (PS: 9808); yet as it progresses in time, spirit internalizes and admits these objects as truly its own. The return to itself from alterity demands that spirit 'has to penetrate and digest this entire wealth of its substance' (PS: $\uparrow 808)$.

The digestive metaphor appears again in a lecture that Hegel delivered in 1809, when he was rector of the Gymnasium in Nuremburg. The lecture, 'On Classical Studies', addresses the place of Greek and Roman literature in the German curriculum. In this address, the pedagogical question of whether classical studies should be replaced by the study of sciences in German is specifically tied to the role that the knowledge of antiquity plays in the stimulation, development, exercise, and improvement of the German soul (CS: 325/317). ${ }^{12}$ Hegel considers the study of Greek literature to be essential to the progress of German culture. Yet for genuine progress to take place, it is necessary not merely to preserve antiquity as an object of erudition, segregating philological study from all other fields of study, but to 'appropriate the world of antiquity not only to possess it, but even more to digest and transform it' (CS: 327/320-21) Here again, the exteriority of the object is 


\section{Peer Gynt and Oedipus}

cancelled once it becomes a part of the mind, which thus overcomes otherness. Like someone growing stronger and healthier by nourishing themselves on superior foods, digesting the Greeks improves the Germans' own being (CS: 325/318), for theirs is 'the most noble food' (CS: 326/319).

The digestive mind is not unlike an animal, an organism in which, according to Hegel, spirit is already individualized (as opposed to lower geological and vegetable organisms, which do not constitute subjects). ${ }^{13}$ In the Philosophy of Nature, Hegel portrays animals as possessing 'a true, self-subsistent self which has attained to individuality' ( $P N$ : $\$ 351 Z \delta, 355)$. Despite their self-subsistence, animals are finite and marked by lack, of which they want to rid themselves. Lack and the urge to get rid of it, in turn, make them depend upon others (PN: $\$ 359,385)$. Lack makes the animal turn outwards, towards the world, in search of food. By eating, the animal brings the external thing into a 'living, absolute unity' with itself. Eating, digesting, are forms of assimilation, that enables 'the conversion of the externality into the self-like unity' (PN: $₫ 363,393$ ).

This encounter between the living, animal organism and the objects on which it feeds is famously replayed in the Phenomenology of Spirit, in the section on selfconsciousness. Dominated by lack (desire), consciousness continuously reaches out to satiate its desire by assimilating objects, those others that are external to it. Encountering an other that is 'equally independent' (PS: $\mid 182)$, and thus resistant to assimilation, consciousness responds aggressively, aiming at 'the death of the other' (PS: 1 187). At this point, the famous struggle to death begins, and with it the master/slave dialectic is set in motion. Relevant to our discussion, however, is the hostile encounter between consciousness and the unassimilable other, who, from consciousness' point of view, challenges its integrity and our wellbeing. Although in the Philosophy of Nature Hegel stresses that digestion, as such, requires that the food be recognized in its alterity (otherwise it would not be digested, as the body does not work to dissolve itself ( $P N$ : $\$ 365 Z$ ), the organism must not be 'actively hostile' to the other, for if it were, its own life-processes would be destroyed. Thus, Hegel notes, 'If the organism were actively hostile to the non-organic, it would not come into its own, for the organism is precisely the mediation which consists in involving itself with the non-organic and yet returning into itself' (PN: \$365Z). Hence, in overcoming otherness by digestion, biological or mental, a balance must be struck between hostility and approval. Moreover, eventually, hostility must be overcome, and this overcoming is what allows the animal to become itself. In other words, by digesting or assimilating the other, the animal truly becomes what it is: 'Through this process of assimilation, therefore, the animal becomes in a real way for itself $[\ldots]$ has proved itself to be an animal individual' (PN: \$365Z).

But there are edible and inedible others. The former, digestible and assimilable, nourish animals and humans, enabling them to grow and become who they are; the latter arouse hostility and often get stuck, as it were, in Hegel's throat, as 


\section{Lior Levy}

they can neither be digested nor spat out. Such are, for example, 'multiform sphinxes, with lion's bodies and virgin's heads' (PH: 213/307), which Hegel finds 'repulsive' (PH: 211/304). ${ }^{14}$ Indeed, as we saw, Hegel thinks that the Greek legend of Oedipus 'wonderfully' surprises us (PH: 220/317) when we find in it traces of an 'immense' (ungeheuren) — and hence too big to swallowEgyptian sphinx (PH: 200/290).

Nonetheless, Hegel also describes in his lectures the process by which the Egyptian 'monstrous productions' (PH: 207/299), which are part of a world that 'is alien to us' (PH: 211/304), have ceased to be other. This is what happens, for example, when they find their way into Greek myths. According to Hegel, although the Greeks:

certainly received the substantial beginnings of their religion, culture, their common bonds of fellowship, more or less from Asia, Syria and Egypt $[\ldots]$ they have so greatly obliterated the foreign nature of this origin, and it is so much changed, worked upon, turned round, and altogether made so different, that what they, as we, prize, know, and love in it, is essentially their own. (LPH: 150/174)

In other words, Greece digested Egypt and in so doing, altered it, made it its own. It did this to such a degree that nothing foreign or alien remained in it. When the sphinx, for example, was eaten by the myth of Oedipus, it was made part of Greece, and in this respect was altered in a way that renders it digestible and palatable to the modern subject, according to Hegel.

Digestion is not a mechanical process, wherein the subject and the object remain external to each other; it is rather a process by which the two become interrelated, through which both subject and object undergo changes: the object is broken, assimilated into the body, which in turn is also changed, its lack or hunger is replaced by satiation, and the animal becomes stronger by fusing with the ingested material (PN: \$362Z). Spiritual digestion is similarly distinguished from other relations between self and other. In his address, while presenting his vision for the role of classical education in the German curriculum, Hegel denounces the 'deficient methods which often degenerated into a merely mechanical procedure' (CS: 322/315). When Greek and Latin are treated as relics of a distant past, 'superfluous learned antiquities' (CS: 324/317), when they are studied through mechanical processes of memorization, for example, they fail to be integrated into the mind of the student and do not become one's own. But spiritual and cultural growth, according to Hegel, is incongruent with such a mechanistic approach:

The progress of culture must not be regarded as the quiet continuation of a chain in which the new links, though attached to 


\section{Peer Gynt and Oedipus}

the older without incongruity, are made of fresh material, and the work of forging them is not directed by what has been done before. On the contrary, culture must have earlier material on which it works and which it changes and modifies. (CS: 327/320)

Hegel makes it clear, here and elsewhere, that Greek culture is of particular importance to one who wants to be at home in the world, to overcome alterity and otherness. The Greeks themselves laboured to make their world their home, and so they allow moderns to recognize themselves in a distant, Greek image. As we saw, according to Hegel's reading of the transition from Egypt to Greece, in overcoming the Egyptian enigma, replacing the question with an answer, the Greeks digested what was until then other and remote. Hence, 'the common spirit of homeliness' unities antiquity and 'men of education in Europe, and more particularly [...] us Germans' (LHP: 149-50/173-74). In order to assimilate the Greeks, German youth must overcome the feeling that Greece and Rome are part of 'a remote and foreign world' (CS: 328/321). Despite the fact that, as we saw, the other must be and appear as other in order to be digestible, they must not be or seem so remote as to resist digestion.

'In ordinary life', says Hegel in his Lectures on the Greeks, 'we like best the men and families that are homely and contented in themselves, not desiring what is outside and about them, and so it is with the Greeks' (LHP: 150/174). Oedipus is of course one crucial anomaly — for his desire to solve the various riddles dogging his existence has rendered him unhomely, literally and metaphorically. In the previous section, I argued that Ibsen is critical of Hegel's 'repression' of otherness or alterity in Oedipus' story, in that even the enigma of the Sphinx that appears in the myth is legible only from the perspective of the modern German subject (who assimilated the Greeks, who, in turn, at least on Hegel's reading, assimilated the East). But then again, Hegel would probably think of Peer's journeys far from home as mistaking 'distance for profundity' (CS: 328/321), and thus not at all like the recommended metaphorical journeys in the course of which otherness is assimilated to the self, and the person feels so at home in the world that she can stop desiring 'what is outside and above them' (LHP: 150/174). We ought to pursue metaphorical journeys in which we become separated from ourselves, but 'at the same time' have 'the cardinal means of returning to ourselves' (CS: 328/321). The dream of leaving for an unknown land and 'living like Robinson Crusoe on a distant island', characteristic of youth, is 'illusory' (CS: 328/321) and should be abandoned. It is a curious choice of example, perhaps, as one of Crusoe's main anxieties while living on that distant island was about being eaten by cannibals. 


\section{Lior Levy}

\section{Ibsen and Oedipus, once again}

Oedipus is a trope that enables Ibsen to explore the manner in which modernity (which he approaches through Hegel's reading of Egypt and Greece) is invested in positing Greece, Apollo, or more generally philosophical reason as its forerunner. As a figure who embodies the connection between self-knowledge and knowledge or recognition of the past, Oedipus is well-suited for use as a metonym for modernity's own relationship to the past. As I hope to have shown, Peer Gynt questions the position from which moderns read Oedipus as a foundation of their own present, exposing the particular attachments moderns have to what is posited as modernity's tradition. They turn out to be attachments that reveal our present preoccupations more than the truth of the past.

Indeed, Ibsen's Peer Gynt as a whole expresses an amused disrespect towards tradition. Readers of the drama are no doubt familiar with Peer's light-heartedness, which is directly connected to his refusal to carry the burden of the past. The drama presents his restless travels around the globe, accompanied by shifts of identity, desires and values. Peer thinks of himself through the image of the onionlayers arranged over nothing in particular, without a kernel, just coatings randomly wound around one another. As he transitions from one role to another, a layer is peeled off, leaving no particular mark, no trace. He feels no debt to tradition- the drama opens with his appropriation of a folk tale, which leads his mother to accuse him of being a liar, calling him a digter, a term that denotes both a poet, who creates fictions, and one who conjures untruths. Peer's changing response to being called this is a testimony to the ambiguity embedded in the term; he is both offended (Ibsen 2005: 148; Ibsen 2009: 24) and proud to be described in this way (Ibsen 2005: 184; Ibsen 2009: 79). We see that the poet and the liar coincide in Peer.

Unlike Oedipus, Peer does not care whose story it was that he now tells, that he makes his own. He does not bother to trace a line between present and past, even when he is acting the role of a scientist, an archaeologist in search of the truth of the past. As Peer the teller of stories is evaluated in the drama, we learn that the affinity between the poet and the liar is not so much to do with their mutual task of abandoning the factual world. In this text, truth is not merely something that can be arrived at through a positivist search for the facts that correspond to the tale. Peer is a digter not merely because his story lacks factual roots, or because one cannot determine whether it occurred or not. Peer is a poet/liar, a poet turning into a liar and vice versa, because the fiction he creates is not genuinely his. In Peer Gynt the meaning and value of being a digter is related to the authority one has to tell a story. This question in turn hinges on whether this story is the poet's own personal and idiosyncratic creation, or whether it belongs to and draws on a broader narrative in which the poet himself partakes. 


\section{Peer Gynt and Oedipus}

Peer Gynt turns this into a meta-poetic question: what is the status of the work itself, a work that appropriates mythical elements and folk materials? How does it situate itself in relation to the creative and cultural past from which it grows? This question is made explicit in Act Five when, in a self-referential movement, the text unites the past of its protagonist with the extra-dramatic folkloric past from which both Peer and Peer Gynt as a whole borrow. When Peer returns to his childhood village as an old man, a group of young men canonize his stories, recounting his tales-some of them belonging to his personal past, some of them drawn from a rich stock of folktales - as past facts: one boy is proud of a rare find, a casting-ladle in which Peer cast his silver buttons (Ibsen 2005: 221; Ibsen 2009: 139); another, holding a reindeer's skull, boasts of owning the remains of the creature that carried Peer over the Gendin Ridge (Ibsen 2005: 222; Ibsen 2009: 140). Peer's biographical past - itself part of a fictional plot—-becomes one further root of the drama in a folkloric, unidentified past; it becomes another stock of stories from which generations will draw. With this, the lines between fact and fiction are called into question, and with them the authority of the past itself as a point of origin for the present. As I hope to have shown, by casting Peer as Oedipus in Act Four, the drama leads us to re-examine the authority of the past as an absolute point of beginning, a definite ground for the modern sense of self. For not only does it ask us to remember that the past gains its authority through the horizon of the present, but also questions, on the shifting terrain of present needs and interests, the way we configure our Egyptian and Greek forbears, and the cultures they have bequeathed to us. For that configuration is inevitably contested when we realize that it mirrors the modern self-image. Called perhaps by Oedipus and the Sphinx, Peer is like a traveller in time, searching out and questioning the would-be stable points of reference laid down by Hegel, a master of historical consciousness. ${ }^{15}$

\section{Lior Levy \\ University of Haifa, Israel \\ levyliord@gmail.com}

\section{Notes}

1 Abbreviations used

CS = Hegel, 'On Classical Studies', in On Christianity: Early Theological Writings, trans. T. M. Knox (New York: Harper and Brothers, 1961)/Nürnberger und Heidelberger Schriften (Frankfurt: Suhrkamp, 1971). 


\section{Lior Levy}

LFA = Hegel, Hegel's Aesthetics: Lectures on Fine Art, trans. T. M. Knox, 2 vols. (Oxford: Oxford University Press, 1975)/Vorlesungen über die Ästhetik (Frankfurt : Suhrkamp, 1970).

LHP $=$ Hegel, Lectures on the History of Philosophy, Volume 1: Greek Philosopby to Plato, trans. E. S. Haldane and F. H. Simson (Lincoln: University of Nebraska Press, 1995)/Vorlesungen über die Geschichte der Philosophie I (Frankfurt: Suhrkamp, 1971).

PH = Hegel, The Philosophy of History, trans. J. Sibree (New York: Dover, 1956)/Vorlesungen über die Gescichte der Philosophie (Stuttgart: Reclam, 1961).

PN = Hegel, Philosophy of Nature, trans. A. V. Miller (Oxford: Clarendon Press, 1970).

PS = Hegel, The Phenomenology of Spirit, trans. M. Inwood (Oxford: Oxford University Press, 2018).

2 The influence of Hegel's aesthetics on Ibsen, as on other Scandinavians at the time, is also discussed in Moi (2006: 74) and Johnston (1980: 3-27), who even refers to Ibsen's early plays as 'conscious experiments in Hegelian aesthetic theory' (1980: 4). However, my own reading, which focuses on Oedipus as a literary trope by means of which Ibsen criticizes Hegel's understanding of subjectivity and its relationship to history, challenges Johnston's claim that Hegel's system puts such pressure on Ibsen's work, that 'he takes it too seriously to play with it' (1980: 5). By casting Peer as Oedipus, Peer Gynt playfully revisits the relationship that Hegel sets up, in his references to Oedipus and elsewhere, between truth and introspection.

${ }^{3}$ Recently, both Asbjorn Aarseth and Kristin Gjesdal have addressed the different modes in which the text relates to the past by exploring Hegelian influences on the drama. Following the evidence for Ibsen's familiarity with Hegel's work, Aarseth and Gjesdal turn to Hegel's elaborate discussion of Egyptian art in his Lectures on Aesthetics as well as his Phenomenology of Spirit, using the developmental accounts in these texts, to which both temporality and progress are crucial, to shed light on themes they find central to Peer Gynt: the contrast between the human and the animal and the theme of 'the beast in man' (Aarseth 2001: 537); the dialectic between self and other and the limitations of the philosophical conception of alterity (Gjesdal 2007: 80). The scope of this essay does not allow me to examine their different readings in great detail-one notable difference between them is that whereas Aarseth reads Ibsen as Hegelian through and through, Gjesdal finds a critique of Hegelian Eurocentrism in the drama-but it is worth noting that according to both, the Hegelian influences crystalize in the fourth act, which depicts Peer's adventures in Africa. They find thematic affinity between Peer's visit to Egypt and Hegel's discussions of Egyptian art, as well as between Peer's later encounter with Herr Begriffenfeldtpotentially a reference to Hegel himself (Gjesdal 2007: 75) — and his visit to the madhouse in Cairo, a visit understood in relation to Hegel's discussion of the dialectic of self and other in the Phenomenology of Spirit (Gjesdal 2007: 75-79; see also Hammer 2009: 39).

${ }^{4}$ Having been educated in a system that, under the influence of Joachim Winckelmann, made the study of Hellenic culture a central component in the curriculum (Rhodes 1995: 22-23), Ibsen was no doubt familiar with Sophocles' tragedy.

5 As Rachel Falkenstern (2018) recently demonstrated, Oedipus' tragedy is rooted, according to Hegel, in his inability to be conscious of the tension between the conscious and the unconscious 


\section{Peer Gynt and Oedipus}

dimensions of his action, or between his intentions as externalized in his action and the objective truth revealed to him later.

${ }^{6}$ In a letter to his friend Friedrich Neithammer, sent just after the completion of the Phenomenology of Spirit in 1806 and with the heading 'The Day the French Occupied Jena and the Emperor Napoleon Penetrated its Walls', Hegel provides a similar description of Napoleon: 'I saw the Emperor-this world-soul_riding out of the city on reconnaissance. It is indeed a wonderful sensation to see such an individual, who, concentrated here at a single point, astride a horse, reaches out of the world and masters it' (Hegel 1984: 114). Napoleon embodies, through contraction and expansion, the relationship between part and whole that Hegel's philosophy conveys. Is not the Phenomenology itself 'the expansion' of spirit, which 'has for its path the recollection of the spirits as they are within themselves' (PS: $\mid 808$ ), so that it too, as a text, while being a contraction to a single (temporal) point, reaches out of time and history to master it? Yet Hegel masters the world even more than Napoleon himself, for he sees Napoleon on reconnaissance and knows what he is doing, whereas Napoleon remains ignorant of what Hegel is doing. In 1814, Hegel writes again about Napoleon to Neithammer, this time associating the emperor with Oedipus: 'It is a frightful spectacle to see a great genius destroy himself. There is nothing more tragic' (Hegel 1984: 307). Napoleon becomes a tragic hero, selfdestructive in his refusal to compromise in ways that would preserve his regime. In his onesidedness, he is not unlike Oedipus, whose wisdom was both a gift and a curse, leading to his fall. Napoleon the tragic hero is both admired and pitied; he is a precondition for the German ability to unite political revolution and moral inwardness (which the French were unable to attain), but he himself remained ignorant of these achievements. In the same letter, Hegel prides himself on having predicted Napoleon's fall. 'In my book, which I completed the night before the battle of Jena', writes Hegel, retrospectively self-interpreting the Phenomenology, 'I said [...] "absolute freedom [...] out of its own self-destructive actuality over into another landI had in mind here a specific land of self-conscious spirit" (Hegel 1984: 307). Napoleon, the admirable individual, is a tragic hero, a victim of history who was, unlike Hegel, merely an instrument of the absolute, and whose own development he could not have foreseen.

${ }^{7}$ In the Logic, Hegel says that childlike innocence is attractive only because it calls to mind what lies beyond it, the achievement of mature spirit, which, unlike the natural gift of childhood, 'must be acquired by 'the labor and culture of spirit'. In a similar vein, Hegel continues, 'the words of Christ, "Except ye become as little children", etc. are very far from telling us that we must always remain children' (Hegel 1975: 34).

${ }^{8}$ Maria Rosa Menocal, writing about the nineteenth century, notes similarly that 'the proposition that the Arab world had played a critical role in the making of the modern West, from the vantage point of the late nineteenth century and the better part of this century, is in clear and flagrant contradiction of cultural ideology' (Menocal 1987: 6).

${ }^{9}$ Revealing himself behind the sphinx is a philosopher by the name of Herr Begriffenfeldt, who crowns Peer as an emperor (an allusion, perhaps to Napoleon and, via Napoleon, to Oedipus). In the following scene, the philosopher takes Peer to a mad house in Cairo, presenting his arrival as a fulfilment of a prophecy — the emperor has come to emancipate the dwellers of the asylum. 


\section{Lior Levy}

Like Oedipus, who is crowned as king after his victory over the sphinx and his removal of the first plague from Thebes, Peer is declared an emperor by Bergiffenfeldt because he fathomed the riddle of the sphinx. The Peer-Oedipus relationship continues to develop in this scene, taking on different emphases, turning to examine selfhood and the role of reason as themes. For analyses of Peer's visit in Cairo as a critique of Hegel's Philosophy, see Gjesdal (2007) and Hammer (2009).

${ }^{10}$ See e.g., Kaufmann (1966: 117-18) and Harris (1997: 47-48).

11 The plot of Peer Gynt is also structured as a homecoming, but as I will show in the next and final section, Peer's journey lacks continuity and development and is instead fragmented, with different scenes arbitrarily juxtaposed (see Lisi 2008: 54-55). In this context, Ibsen's fragmented epic should be studied vis-à-vis Hegel's theory of the ancient epic, which connects the epic to the emergence of Greek society, in so far as it provided the Greeks with an image of themselves. Ibsen's Peer Gynt offers a critical image of modern, national identity, beginning with the protagonist's escape from his conservative, backward looking hometown, and continuing by ridiculing, indeed even severing, all connections between Peer and his social environment.

12 See Vered Lev Kenaan's (2019) rich reading of this address, which portrays it as the site for understanding both Greek and German reworking of their history, and highlights the consequent processes of repression and idealization that grow out of this reworking.

${ }^{13}$ Hegel's account of digestion in the Philosophy of Nature is outlined by Jane Dryden (2016), who positions the gut as the locus for a meeting between self and other.

${ }^{14}$ Hegel uses the adjective widrig, the unassimilable is adverse, unbeneficial, but even disgusting (as in e.g., 'widriger Geruch').

${ }^{15}$ I thank Mark Joseph for his superb editing as well as for his astute, philosophical comments and references. I am grateful to Vered Lev-Kenaan and Kristin Gjedsdal for inspiring conversations on Oedipus, Ibsen and the relationship between them. Finally, I thank Muneera Abu Roken for her help in obtaining the rights for the image. Research for this essay was supported by the Israel Science Foundation (grant 1990/19).

\section{Bibliography}

Aarseth, A. (2001), 'Peer Gynt and Hegel's Ideas on Egyptian Art', Scandinavian Studies 73:4: 535-46.

Ackerman, G. M. (1986), The Life and Work of Jean-Leon Gerome. New York: Sotheby's Publishing.

Dryden, J. (2016), 'Digestion, Habit and Being at Home: Hegel and the Gut as Ambiguous Other', PhaenEx 11:2: 1-22.

Falkenstern, R. (2018), 'Hegel on Sophocles' Oedipus the King and the Moral Accountability of Ancient Tragic Heroes, Hegel Bulletin 41:2: 159-76.

Gjesdal, K. (2007), 'Ibsen and Hegel on Egypt and the Beginning of Great Art', Hegel Bulletin 28:55/56: 67-86. 


\section{Peer Gynt and Oedipus}

Goldhill, S. (2015), 'The Ends of Tragedy: Schelling, Hegel, and Oedipus', in J. Billings and M. Leonard (eds.), Tragedy and the Idea of Modernity. Oxford: Oxford University Press.

Hammer, E. (2009), 'The Question of Selfhood in Ibsen's Peer Gynt', Ibsen Studies 1:1: 34-49.

Harris, H. S. (1997), Hegel's Ladder. Indianapolis: Hackett.

Hegel, G. W. F. (1975), Logic, trans. W. Wallace. Oxford: Clarendon Press.

Hegel, G. W. F. (1984), The Letters, trans. C. Butler and C. Seiler. Bloomington: Indiana University Press.

Hyppolite, J. (1957), 'Phénoménologie de Hegel et Psychanalyse', La Psychanalyse 3: 17-32.

Ibsen, H. (2005), Samlede Verker, vol. II. Oslo: Kagge Forlag.

Ibsen, H. (2009), Peer Gynt, trans. C. Fry and J. Fillinger. Oxford: Oxford University Press.

Johnston, B. (1980), To the Third Empire. Minneapolis: University of Minnesota Press.

Kaufmann, W. (1966), Hegel: A Reinterpretation. Garden City NY: Anchor Books. Lev Kenaan, V. (2019), The Ancient Unconscious: Psychoanalysis and the Ancient Text. Oxford: Oxford University Press.

Lisi, L. (2008), 'Allegory, Capital, Modernity: Peer Gynt and Ibsen's Modern Breakthrough', Ibsen Studies 8:1: 43-68.

Menocal, M. R. (1987), The Arabic Role in Medieval Literary History. Philadelphia: University of Pennsylvania Press.

Moi, T. (2006), Henrik Ibsen and the Birth of Modernism. Oxford: Oxford University Press.

Oxfeldt, E. (2005), Nordic Orientalism: Paris and the Cosmopolitan Imagination 18001900. Copenhagen: Museum Tusculanum Press.

Rees, E. (2008), 'Tropological Turns in Peer Gynt', Ibsen Studies 8:2: 150-72.

Rhodes, N. (1995), Ibsen and the Greeks. Lewisburg: Bucknell University Press.

Sophocles (1994), Ajax, Electra, Oedipus Tyrannus, trans. H. Lloyd-Jones. Cambridge: Harvard University Press. 